\title{
Examining the Attitudes and the Opinions of Teachers about Altruism
}

\author{
Ayşegül Palta \\ Department of Educational Sciences, Faculty of Education, Hakkari University, Hakkari, Turkey
}

Copyright $\bigcirc 2019$ by authors, all rights reserved. Authors agree that this article remains permanently open access under the terms of the Creative Commons Attribution License 4.0 International License

\begin{abstract}
The objective of this paper is to examine the attitudes and the opinions of teachers about altruism. Research was conducted with 289 teachers. Research design is mixed research design. "Teacher Altruism Scale", which was developed by Yavuzer, Gazioğlu, Yıldız, Demir, Meşeci, Kılıçaslan \& Sertelin (2006) and Altruism Interview Form developed by researcher were used. Independent Samples T Test and Kruskal Wallis Test and content analysis were used in this study. According to quantitative findings, altruism attitude of teachers do not differ according to genders, marital status and the reasons for choosing teaching profession and do not differ according to branch and seniority either. According to qualitative findings, most of the teachers stated that their colleagues made attempts on the needs related to teacher training. And also, most of the teachers stated that their colleagues share educational issues.
\end{abstract}

Keywords Altruism, Teacher, Opinion, Attitude

\section{Introduction}

The teaching profession is not only knowing the subject well or transferring information in a systematic way but also working for the good of mankind. This profession is defined as the integration of feelings, helpfulness, confidence, respect and friendship (Hayes, 2004). Moral behavior and responsibility is the basis of teaching (Freeman, 1988).

Teaching is considered as a sacred profession and believed to require sacrifice. Özday1 (1992) found that men and women teachers stated the reasons for choosing teaching profession as professional love, spiritual aspect of the profession and ideal for themselves. In addition, it is determined that helping others and responsibility are the two most satisfying variables related to teaching profession. Hoyle \& John (1995) cited by Locke, Vulliamy, Webb \&
Hill (2005) stated that altruism is one of the three basic elements of teaching profession.

The concept of altruism was told by August Comte for the first time and he defined it as "living for others" (Comte, 1851). According to Piliavin \& Charng (1990), altruism is defined as all of the values, preference and behaviours that are oriented to meet the needs of others rather than their own desires and needs. Myers (1993) defines altruism as helping someone with no thought of personal gain. According to Y1lmaz (2010), altruism is helping each other. Considering the teaching profession Rafky \& Beckerman (1972) asserted that altruism means that professionals work for the good of customers, society and have no selfish purposes.

Altruism is the primary criterion used to describe teacher (Karadeniz, 2007). Scott and Dinham (1999) identified elements that express teacher strongly: altruism, commitment and personal development. Altruistic motives motivate teachers to choose teaching as a profession and maintain it (Mutafçılar, 2008). Altruistic teachers work for the good of community and students and have non-selfish purposes (Rafky \& Beckerman, 1972). Studies indicate that teachers show altruistic behaviors, establish sympathetic and affectionate relationships with their students (Bergem, 1990; Lortie, 1975; Morgan, 1984; Nias, 1989). It is seen that there are studies examining the relationship between altruism and moral reasoning, assertiveness, empathy, well-being in the literature (Akyel, 1986, Duru, 2002, İşmen \& Yıldız 2005, Kasapoğlu, 2014).

Conducting researches about altruism with teachers is important. Attitudes and opinions of teachers are important elements within the body of school. During the research of literature, no study has been founded on the attitudes and opinions of teachers about altruism. So, after this study, filling these blanks in literature and providing important benefits to education stakeholders is expected. In this research, it was aimed to reach the findings, which help improve the teacher training programs. 


\section{Methodology}

\subsection{Research Model}

Research design is determined as mixed method. Survey model and phenomenological design were used.

\subsection{Population and Sample}

The population of the study consists of teachers. Convenience sampling method was preferred and the research was conducted with 289 teachers.

\subsection{Instruments}

"Teacher Altruism Scale", which was developed by Yavuzer, Gazioğlu, Yıldız, Demir, Meșeci, Kılıçaslan \& Sertelin (2006) and Altruism Interview Form developed by researcher were used.

Teacher Altruism Scale
It was developed by Yavuzer and et al. (2006). The tool had the structure of four dimensions consisting of 18 items. Cronbach alpha reliability coefficient of scale was found 0.73 by Yavuzer and et al. (2006).

Teacher Altruism Interview Form

Demographic characteristics and the following questions were asked to the participants and questions are below:

1. Do the teachers in your school attempt for educational needs? What are the reasons for this?

2. Do the teachers in your school share educational issues with each other? What are the cooperation examples?

\subsection{Analyses}

Independent Samples $\mathrm{T}$ Test and Kruskal Wallis Test and content analysis were used in this study.

\section{Results}

Quantitative findings are as follows:

Table 1. Altruism Attitudes of Teachers According To Gender

\begin{tabular}{ccccccc}
\hline Points & Gender & $\mathrm{N}$ & $\mathrm{M}$ & $\mathrm{S} . \mathrm{d}$. & $\mathrm{t}$ & $\mathrm{p}$ \\
\hline \multirow{2}{*}{ Altruism } & Male & 119 & 68,1092 & 13,54264 & \multirow{2}{*}{02} &, 99 \\
& Female & 148 & 68,0811 & 12,02012 & & \\
\hline
\end{tabular}

Altruism attitudes of teachers don't change with regard to gender ( $\mathrm{p}>.05)$.

Table 2. Altruism Attitudes of Teachers According To Marital Status

\begin{tabular}{ccccccc}
\hline Points & Marital status & $\mathrm{N}$ & $\mathrm{M}$ & $\mathrm{S} . \mathrm{d}$. & $\mathrm{t}$ & $\mathrm{p}$ \\
\hline \multirow{2}{*}{ Altruism } & Married & 230 & 67,6348 & 12,74700 & \multirow{2}{*}{, 48} &, 14 \\
& Single & 37 & 70,9459 & 12,15855 & & \\
\hline
\end{tabular}

Altruism attitudes of teachers don't change with regard to marital status ( $\mathrm{p}>.05)$.

Table 3. Altruism Attitude of Teachers According To Branch

\begin{tabular}{cccccccc}
\hline Points & Branch & N & M & S.d. & T & P \\
\hline \multirow{2}{*}{ Altruism } & $\begin{array}{l}\text { Branch } \\
\text { teacher }\end{array}$ & 199 & 66,7337 & 13,00988 & $-3,32$ &, 00 \\
& Class teacher & 68 & 72,0735 & 10,87420 & & \\
\hline
\end{tabular}

Altruism attitudes of teachers change with regard to branch $(p<.05)$. Points of class teachers are higher than the others.

Table 4. Altruism Attitudes of Teachers According To Seniority

\begin{tabular}{cccccc}
\hline Points & Seniority & N & Mean Rank & $\mathrm{X}^{2}$ & $\mathrm{p}$ \\
\hline \multirow{3}{*}{ Altruism } & $1-5$ years & 25 & 99,38 & & \\
& $6-10$ years & 58 & 122,68 & 11,13 &, 03 \\
& $11-15$ years & 70 & 132,99 & 142,50 & \\
& $16-20$ years & 75 & 158,49 & \\
\hline
\end{tabular}

Altruism attitudes of teachers change with regard to seniority $(\mathrm{p}<.05)$. Teachers whose seniority is 21 years and over have highest altruism mean ranks and teachers whose seniority is 1-5 years have lowest altruism mean ranks. 
Table 5. Altruism Attitudes of Teachers According to the Reason for Choosing Teaching Profession

\begin{tabular}{|c|c|c|c|c|c|}
\hline Points & The reason for choosing teaching profession & $\mathrm{N}$ & Mean Rank & $x^{2}$ & $\mathrm{P}$ \\
\hline \multirow{6}{*}{ Altruism } & Parents request & 31 & 131,63 & \multirow{6}{*}{, 13} & \multirow{6}{*}{1,00} \\
\hline & My ideal & 113 & 133,82 & & \\
\hline & University entrance exam & 80 & 135,93 & & \\
\hline & Coincidence & 23 & 133,35 & & \\
\hline & Friends & 2 & 122,25 & & \\
\hline & Other & 18 & 132,75 & & \\
\hline
\end{tabular}

Altruism attitudes of teachers don’t change with regard to the reason for choosing teaching profession $(\mathrm{p}>.05)$.

Qualitative findings are as follows:

Table 6. Reasons for Attempts of Teachers about Their Colleagues' Educational Needs

\begin{tabular}{cll}
\hline No & Categories & $\mathrm{f}$ \\
\hline 1. & Competence feeling (P3) & 1 \\
2. & Professional development (p4, p10,p12, p16) & 4 \\
3. & Achievement motivation (p13) & 1 \\
4. & Education quality (p21,p22) & 2 \\
\hline
\end{tabular}

Most of the teachers stated that their colleagues made attempts on the needs related to teacher training. As shown in Table 8, the reasons for attempts on the needs related to teacher training has four categories. The most repeated category was "professional development". The statements of participants were as follows:

$P$ 21. When teachers in my school feel a need related to education, they make this happen by reporting this situation to the school board as verbal or written. Because it is important for teachers that students have the highest quality education. They do not avoid from making sacrifice in order to improve the quality of education.

$P$ 12. Yes, teachers in this school make attempts on the needs related to teacher training. Because teaching profession is open to development. Teachers here are aware of that.

P 3. Yes, teachers make attempts on the needs related to teacher training in order to feel themselves competent.

Table 7. Cooperation Examples of Teachers with Each Other

\begin{tabular}{cll}
\hline No & Categories & $\mathrm{f}$ \\
\hline 1. & $\begin{array}{l}\text { Cooperation in Celebrations and } \\
\text { commemorations (p2) }\end{array}$ & 1 \\
2. & $\begin{array}{l}\text { Educational activities } \\
\text { sharing(p3,p21,p8,p17,p18,p22) }\end{array}$ & 6 \\
3. & Exams sharing (p6,p8) & 2 \\
4. & Educational games sharing (p10, p21) & 2 \\
5. & Book sharing (p11,p3) & 2 \\
6. & Teaching materials & sharing(p11,p18,p6,p17,p18,p22) \\
7. & Change of watch days(p18,p21) & 6 \\
8. & Expression techniques (p3,p17) & 2 \\
\hline
\end{tabular}

Most of the teachers stated that their colleagues share educational issues. As shown in Table 7, Cooperation examples of teachers with each other have eight categories. The most repeated categories were "educational activities and teaching materials". The statements of participants were as follows:

P3. Yes, we share our books and course materials. Even in breaks, we tell each other how to teach subject better. If necessary, we made a special lecture for students.

P17. We certainly share...we share our worksheets that we prepared. We tell each other how to teach a certain subject.

\section{Discussion and Conclusion}

Altruism attitudes of teachers don't change with regard to gender, marital status and the reason for choosing teaching profession. Onatir (2008) found that teachers' altruism level did not differ according to gender, marital status, branch and the reason for choosing teaching profession. Mutafçılar (2008) found that teachers' altruism level did not differ according to marital status. Karadağ \& Mutafçılar (2009) found that teachers' altruism level did not differ according to gender and the reason for choosing teaching profession.

Altruism attitudes of teachers change with regard to seniority and branch. However, Onatır (2008) found that teachers' altruism level did not differ according to seniority. Contradiction between Onatır's (2013) study and current study may have occurred due to different sample. Karadağ \& Mutafçılar (2009) found that teachers' altruism level did not differ according to branch and seniority.

Most of the teachers stated that their colleagues made attemps on the needs related to teacher training. The reasons for attempts on the needs related to teacher training have four categories. The most commonly voiced category was "professional development". And also, most of the teachers stated that their colleagues share educational issues. Cooperation examples of teachers with each other have eight categories. The most commonly voiced categories were educational activities and teaching materials.

Seminars on altruism can be organized for teachers to 
create awareness in this regard. A similar study can be conducted with teacher candidates and the results of the studies can be compared. This research can be investigated with different methods and samples and reasons of findings can searched. Variables that affect altruism attitudes may be investigated.

\section{REFERENCES}

[1] Akyel, H. B. (1986). Altruistic behavior and prosocial moral reasoning among Turkish high school students. Unpublished doctoral dissertation, University of Maryland.

[2] Balc1, A. (2011). Social Science Research Methods, Techniques and Principles. Ankara: Pegem.

[3] Bergem, T. (1990). The teacher as moral agent. Journal of Moral Education, 19(2), 88-100.

[4] Comte, A. (1875). System of positive polity. London: Longmans, Green and Co.

[5] Duru, E. (2002). To investigate the relationship between empathy and helping tendency, and examine the difference between helping tendency scores of the groups in terms of some psychosocial variables. Retrieved from 06.06.2016, http://pauegitimdergi.pau.edu.tr/Makaleler/991254288 3-\% C3\%96\%C4\%9ERETMEN\%20ADAYLARINDA\%20\%20 EMPAT\%C4\%B0.pdf.

[6] Freeman, H. R. (1988). Perceptions of teacher characteristics and student judgements of teacher effectiveness. Teaching of Psychology, 15(3), 158-160.

[7] Hayes, D. (2004). Recruitment and retention: Insights into the motivation of primary trainee teachers in England. Research in Education, 71, 37-49.

[8] Hoyle, E. \& John, P. (1995). Professional knowledge and professional practice. London: Cassell.

[9] Işmen, E. \& Yıldız, A. (2005). The relationship between altruism, assertiveness and attitudes towards teaching profession. Educational Administration: Theory and Practice, 11(42), 151-166.

[10] Karadağ, E. \& Mutafçılar, I. (2009). A research on altruısm levels of the primary and secondary school teachers. Ondokuz Mayıs Üniversitesi Eğitim Fakültesi Dergisi, 28, $75-92$.

[11] Karadeniz, G. (2007).To examine the differences between altruistic behaviors of special education teachers and special education teacher candidates. 17. National Special Education Congress.

[12] Karasar, N. (1999).Scientific research method: Concepts, principles, techniques. Ankara: Nobel.

[13] Kasapoğlu, F. (2013). An examination of the relationship between wellness and altruism among college students. Master Thesis. Inönü University, Institute of Educational Sciences, Malatya.

[14] Kasapoğlu, F. (2014). An examination of the relationship between wellness and altruism. Wisdom Home, 7(13),
$271-288$.

[15] Locke, T., Vulliamy, G., Webb, R. \& Hill, M. (2005). Being a "professional" primary school teacher at the beginning of the 21st century: A comparative analysis of primary teacher professionalism in New Zealand and England. Journal of Education Policy, 20(5), 555-581.

[16] Lortie, D. C. (1975). School teacher. Chicago: University of Chicago Press.

[17] Morgan, S. R. (1984). An illustrative case of high empathy teachers. Journal of Humanistic Education and Development, 22(4), 143-148.

[18] Mutafçılar, I. (2008). A research on the historical development of altruism concept and teachers' altruism. Master Thesis. Yeditepe University, Institute of Social Sciences, İstanbul.

[19] Myers, D. (1993). Social psychology. New York: McGraw-Hill.

[20] Nias, J. (1989). Primary teachers talking. New York: Routledge.

[21] Onatır, M. (2008). The relationship between teachers? altruistic behaviors and value preference of teachers. Master Thesis. Yeditepe University, Institute of Social Sciences, İstanbul.

[22] Özday1, N. (1992) The effect of teachers who prefer teaching profession' vocational choice on job satisfaction. M. Ü. Atatürk Faculty of Education Journal, 4, 177-188

[23] Piliavin, J. A.,\& Charng, H. W. (1990). Altruism: A review of recent theory and research. The Annual Review of Sociology, 16, 27-65.

[24] Rafky, D.M., \& Beckerman, M. (1972). Teachers' acceptance of innovations: Self-interest, altruism and professionalization. College Student Journal, 6(4), 68-79.

[25] Scott, C. \& Dinham, S. (1999). The occupational motivation, satisfaction and health of English school teachers. Educational Psychology, 19(3), 287-309.

[26] Yilmaz, K. (2010). Public secondary school teachers' views about organizational citizenship behavior. Ondokuz Mayis University Journal of Faculty of Education, 29(1), 1-16. 